\title{
PARADOXES OF PARTICIPATION OF THE WOMEN LEADERS IN THE UNION PARISHAD IN BANGLADESH: A PHENOMENOLOGICAL ANALYSIS
}

\author{
Mizanur RAHMAN 1
}

DOI: $10.35782 / J C P P .2019 .2 .05$

\begin{abstract}
This paper discusses obstacles of participation of the women leaders (WLs) in the grassroots based local government in Bangladesh, i.e. Union Parishad (UP). Since its inception (1870) till date (2019), local government of Bangladesh has a history of 149 years, but women's representation has been ensured since only 2 decades ago. After enacting reservation quota for women leaders in the sphere of Union Parishad (UP) in 1997, women leaders had to struggle hard to ensure their participation in the UP affairs. Within the span of 2 decades, WLs fails to ensure their effective participation because of some built-in problems of the UP. Against such a context, the paper is aimed at unraveling the research questions: What are the problems WLs are facing in ensuring their participation? The paper is based on phenomenological approach which was supported by case study, content analysis and observation methods. The findings of the paper revealed that women leaders (WLs) identified 3 major challenges towards playing their active role and participation in the UP such as i) patriarchy or male domination, ii) corruption and iii) faulty legal provision imposed upon them. All these problems are problems of local government in particular and Bangladesh society in general. Solution might be changing the legal and structural arrangements in the UP. Improving overall governance couple with reducing malpractices and corruptions can promote having women's rights and privileges better in the UP. More affirmative action such as education facilities should be expanded in the society to enhance women's participation and to modify value system as traditional values help perpetuate patriarchy and other social ills.
\end{abstract}

Keywords: participation, women leaders, local government of Bangladesh, Union Parishad

\footnotetext{
${ }^{1}$ Ph.D., Joint Director, Rural Economics and Management Division, Bangladesh Academy for Rural Development (BARD), Cumilla, Bangladesh. E-mail: mizanbard@gmail.com.
} 


\section{Introduction}

The Union Parishad (thereafter UP) is the lowest unit of local government (LG) in Bangladesh that began functioning in 1870, during the British colonial rule. Since the colonial era, until 1976, there was no provision for women representation in the UP in Bangladesh. In a real sense, women's representation in the UP was ensured in the LG Ordinance of 1997, which made a provision of reservation of one-third seats for women members. During the prolonged 144 (1870 to 2014) years of LG history, important development concerning women's representation took place within the last 17 years that spanned from 1997 to 2014 . However, within these 2 decades, women leaders (thereafter WLs) tried to ensure their rights in the UP. Against such a backdrop this paper aimed at unraveling the grassroots realities of the problems of participation of the WLs in the UP affairs in Bangladesh.

The paper is based on qualitative method. It was deemed that by using qualitative methods, lived and rich experiences, multiple realities, diverse dimensions and dynamics of problems of participation of the WLs could be explored and thus to help unearth the research questions properly. To explore the major problems faced by the WLs, hermeneutical phenomenological approach was adopted. Phenomenology was substantiated by case study to enrich the findings obtained from interview. Author's own observation, gained through his prolonged (about 200 hours) field work, has also been incorporated to prepare this paper. Data were collected during July-December 2015. To support primary data, some secondary data were also used. For phenomenological analysis, data were thematically arranged. As soon as the same theme started repeating, data collection was stopped, but for checking regional variation, data were collected from 19 UPs covering different sociocultural zones $^{1}$ of Bangladesh. Mostly, the WLs were interviewed separately, so that they can share their experiences and realities properly, whereas in few cases, some male members and some community members and leaders were also interviewed for having their perspectives and better understanding the probleme. The whole discussion was recorded with the informed consent of the participants and afterwards transcription was prepared into English from Bengali. In line with the research questions, data were then organized into different thematic areas and afterwards, reducing data from 21 themes, 4 themes were finalized through a rigorous process. For analyzing the essence or meaning of the textual descriptions obtained from the participants, content analysis method was adopted using the relevant literatures from research reports, books, journal articles through a heuristic search from library materials and online both.

\section{Women's representation in the local government in Bangladesh}

The foundation of today's UP was laid down during the British colonial rule with the Village Chowkidary Act of 1870. The ending of British rule in India gave birth of two

1 There are 7 divisions, 64 districts, 507 Upazilas and 4498 Union Parishads in Bangladesh. The sampled 19 UPs were selected covering 5 divisions and 7 districts of Bangladesh i.e. Chittagong, Comilla, Faridpur, Sylhet, Barisal, Bogra and Gaibandha districts. 
different states such as India and Pakistan in 1947. Afterwards, Bangladesh achieved its independence from the internal colonialism of Pakistan in 1971 and inherited LG systems from Pakistan with some modifications in its structure. Since from 1870 the functionaries of local government ${ }^{1}$ were always in the hands of males (Chowdhury et al., 1994, p. 6) and rights to vote in the local bodies were dependent on the educational qualification, possession of property and tax payment etc. (Smock, 1977, p.117; Women for Women, 1992). However, women's representation in the political community was allowed through the Government of India Act in 1935 (Forbes, 2002) but based on the universal adult franchise, women for the first time took part in the election to the rural local bodies in 1956 (Rashiduzzaman, 1968; Inter Parliamentary Union, 1987) and thereby only one female candidate was elected in the UP election of 1956 and 1969 during the Pakistan regime. In the first UP election of Bangladesh in 1973, out of 4352 UPs, only one woman from Rangpur district was elected as the UP Chairman (Alam and Begum, 1974, p.38-51). Afterwards, women's representation to the UP was enshrined by two presidential ordinances namely through Local Government Ordinance of 1976 and Municipal Ordinance of 1977, which for the first time provided a provision of nomination of 2 women members in the UP. Remarkable development regarding women's representation in LG took place during the Ershad regime ${ }^{2}$ through the Union Parishad Ordinance of 1983 that made a provision of nomination of three women members in the UP (Haque, 2003a; Khan, 2011; Khan and Ara, 2006). In 1993, three women members were elected by the 9 elected male members and the Chairman. A major breakthrough in the representation style of women in the UP was made in 1997, which provided one-third reservation for women. By the UP act of 1997, in each Union, three seats are reserved for a woman and accordingly, one woman is elected from three wards, whereas 9 male members are elected from 9 Wards through direct election in the UP.

\section{Literature review}

Bangladesh is predominantly Muslim and with a high degree of religiosity; it is one of the world's most impoverished countries, with more than half of its population living below the poverty line and more than a third (35\%) living in extreme poverty (Chowdhury, 2005, p.22). Rural women in Bangladesh, remain the poorest of the poor; faring worse than men on almost every measure (Alam and Karim, 2007; Mahtab, 2007; Naz, 2006; Hasmi, 2000). Women wage earners in poor households consume on

${ }^{1}$ Here in this paper local government connotes rural local government, more specifically Union Parishad, the oldest rural local government body in Bangladesh. Till 1983, the only local government in Bangladesh was Union Parishad. In the last 149 years that spanned from 1870 till 2019, UP has never lose its representative character and election was continued every 5 years alternate in UP unlike many ups and downs in Bangladesh society.

${ }^{2}$ Hussain Muhammad Ershad was one of the military rulers in Bangladesh. While he was the Chief of Army Staff of the Bangladesh Army, he declared Martial Law following a bloodless coup and became Chief Martial Law Administrator in 1982. Afterwards he became the President of Bangladesh from 1983 to 1990. During Ershad regime, following the suggestions of National Executive Committee for Administrative Reform and Reorganization (NICARR), he undertook substantive reform measures in the sphere of civil administration and local government system in Bangladesh. 
average of 1.3 meals a day, as compared to 2.4 meals eaten by men (Mahtab, 2007). Women are less educated, having a 48\% literacy rate compared with $59 \%$ for males (United Nations, 2007). Women's medical expenditure in the typical household is $45 \%$ compared with $55 \%$ of men (Stalker, 1995). Furthermore, Bangladesh is one of the few countries in the world where women on average die younger than men (Mahtab, 2007). Although half of the population in Bangladesh is women, on an average, they do twothirds of the total works, including household works and received only one-tenth of the world income (Huq, 1995; Hussain, 2002). Participation of women in higher professional and managerial position is very limited.

Critics argue that women's non-participation in political space is a consequence of a number of factors, including women's responsibilities for family and children, the negative attitudes and discrimination of political parties, conservative religious and cultural doctrines, discriminatory socio-economic conditions, electoral systems, the nature of the regime and financial barriers (Rule, 1994a, 1994b; Liswood, 1999; Harris, 2001). The reason behind women's low representation in public office is that there are obstacles to women's full, equal participation in politics. Many of these barriers are deeply rooted in patriarchal structures and attitudes and manifested in the structures and agenda of political parties, unfair electoral voting systems, high costs of elections, and lack of access to training and education (Reyes, 2001). Ensuring women's equal political and economic rights has seemed to cause controversy, disinterested, and denial everywhere (Giele and Asmock, 1977). Moreover, existing laws seem unable to protect women effectively from violence and economic deprivation. There is also very limited women participation in party hierarchical structure.

Against such a backdrop, women's representation in the local government institutions (LGIs) is essential from a political point of view as from the considerations of both equity and production (Quadir, 1993, p.25; Quader and Islam, 1987, p.4). Involvement of women in the LGIs creates a scope for familiarizing them with the democratic system, which acts as a training ground for political education. To develop political awareness and consciousness women should be involved in social, economic and political activities and participation of women in higher decision-making bodies will help them deal with women's issue more successfully (Siddiqui, 1995, p.271-272). In fact, the LGI is the closest and most acceptable level of government to women because it traditionally provides various social services such as electricity, waste disposal, public transport, water, schools, health clinics and other programs relating to poverty reductions and rural development. However, women's participation is ever more marginalized at the LGIs reflecting the social realities of women's subordinate and dependent status and the consequent invisibility of women in public space (Chowdhury, 1994, p.49). Women's participation in the political decision-making process at local level is marginal. In fact, the problems of women's participation are more of structural than organizational. Such structural problems are embedded in widespread illiteracy, confinement in household work, old tradition of subordinate roles, religious and cultural factors and lack of training and motivational facilities (Ahmed and Quader, 1993). Women members are excluded from the UP activities but women's political participation results in tangible gains for democracy, including greater responsiveness to citizen needs, increased cooperation across party and ethnic lines and 
more sustainable peace (Wollack, 2010). Women's political participation has profound positive and democratic impacts on communities, legislatures, political parties and citizen's lives. As women can bring positive changes in democratic practices, therefore it is exigently essential to delve into the participatory politics of women in order to consolidate the grassroots democracy. Therefore, if women can effectively participate in the local government process, women leaders would help other village women to involve them in more income earning opportunities. Against the above backdrop, it is deemed through analysis of women's problems of participation in the sphere of grassroots-based local government in Bangladesh, this paper will help contribute to women's political participation in the UP, which in turn can strengthen local democracy and economy of the country.

\section{Problems of participation of the women leaders in the UP}

Women members identified three major problems in the systemic arrangements of the UP that blocked their participation, which were elucidated beneath one by one incorporating relevant evidences from other studies.

\section{Women members encountering extremely male domination in the UP}

The problem of the male domination lies in the entire UP structure because an UP is composed of 9 male and 3 women members and a Chairman, who being a male promotes the cause of male hegemony in the UP. At the initial stage, the existence of women members was never accepted by the male members and still they are to face a constant male domination in every UP in Bangladesh. The major bottleneck, more specifically the number one problem regarding women's participation in the UP, is male domination, which can be called in terms of "patriarchy" and described in many different ways, but common terms include "gender stratification, gender inequality, female disadvantage, sexism, and patriarchy" (Chafetz, 1990). Patriarchy is a term used to describe the social system of male domination over females, where male domination is built into the social, political and economic institutions of society. Patriarchal societies are characterized by male control of economic resources, male domination of political processes and positions of authority, and male entitlement of sexual services. According to the feminist perspectives, though some societies are more patriarchal than others, all modern societies have a patriarchal structure (Paxton and Hughes, 2007, p.24). Male members never accept women as their colleagues but are rather obsessed with patriarchal beliefs and tenets; they always judge women and perpetually subjugate them to their wishes and demands, which is vividly reflected in the words of a male member. During discussion with the women members of the South Durgapur UP, an old male member, being seriously annoyed with the present author, observing that the entire discussion was going on with women members, and stated the following at the top of his voice:

"It is the male members who brought you in the UP and gave rights to you. He warned the women members not to claim with their rights and said that if women further bother for their rights, they would take away women's right again" (Male Member, South Durgapur UP). 
The above quotation is an extreme opinion enunciated by an old male member. He viewed that instead of discussing with him, the whole discussion was going on with women members, who were talking about some important problems of the UP and at one point he made such a sweeping but bold utterance, which in fact was a true reflection of the attitude of male towards female members. When male members cannot win in depriving women of their due rights in the UP, they try to create problems using different means. Being obsessed and brought up with patriarchal norms and values, the male members' mental make-up is entirely textured by the domination over females, and these male members are never ready to relinquish an iota of power and or authority to the female members, a stance that they have enjoyed from the primitive colonial days to date, which began even before state formation, and the domination of males over female has been continuing without having any change in its forms or styles. It was learnt from one of the female politicians from Central America, that "the patriarchal ideology prevailing in the society is the biggest stumbling block towards participation of women" (Inter-Parliamentary Union, 2000, p.61). The same is the case in the UP in Bangladesh. This is evident from the following example of a woman member in Bethkapa UP, where having a female Chairperson in that Union, their Chairperson tried to distribute projects to women members there equally with the male members but the male members did not accept that and therefore the male members tried to impose their domination using unjust, cruel, and illogical means, which was vividly reflected in the following quotations from a female member, who stated that "when the male members could not defeat or deprive us of our rights, then they tried to suit fake cases against us so that they could dominate over us" (Female Member, Bethkapa UP).

In another case it was found that by struggling with huge male domination the women members were questioning the affirmative action of the government. During the author's discussion with the women members of the Garidaha UP, a female member, mentioned that some male members thought that there was no need of woman members in the UP and she stated the following: "Government had created a problem for us by incorporating us in the parishad rather it was much better if government did not bring us here" (Female Member, Garidaha UP).

Being frustrated from struggling with her rights in the UP, she made the above utterance as she was not able to judge whether the government has blessed her with an opportunity or not. However, bereft of women's minimum rights and shares in the UP, she judged her existence in the UP as a "problem." All over Bangladesh, there is perhaps any UP where such male domination is non-existent; rather, it is ubiquitous, which has been explicitly reflected through the utterance of a woman member from Suvapur UP, who noted the following:

"Always problems occurred particularly with the male members. In Bangladesh there were hardly any UP where such problems were not prevailed. We want our shares and we will never give up our due shares" (Woman Member, Suvapur UP).

Bangladesh overall is still considered as one of the countries with the highest level of gender discrimination and patriarchal structures, embedded at all levels of society. Women suffer from gender-specific discrimination, such as early marriage practices, gender-based violence, biased inheritance and property laws, restriction of mobility and 
access to services, participation in public spaces, etc. (Sikder, Engali, Byrne, \& Tabet, 2011). Inequality of women's representation in politics is also a consequence of a "number of factors, including women's responsibilities for family and children, the negative attitudes and discrimination of political parties, conservative religious and cultural doctrines, discriminatory socio-economic conditions, electoral systems, and the nature of a regime and financial barriers" (Rule, 1994a, 1994b; Liswood, 1999; Harris, 2001). The problem of male domination in the UP cannot be exaggerated. One woman, member from Gunabati UP added the following:

"In fact, the root cause of all problems in the UP is the male members, the Chairman did not create much problem, but the main culprits are the male members. We are 3 female members, but they are 9 male members, so here lay the problem" (Woman Member, Gunabati UP).

In a highly traditional socio-cultural structure and belief system, women's public political participation is not encouraged instead, women are encouraged to assist in the domestic activities and to be docile, tame and submissive. In most cases the elected women members are systematically discriminated by males, verbally abused, always assigned to a specific development committee, excluded from arbitration committee, etc. (ADB, 2001; quoted in Gani and Sattar, 2004). Due to male domination women leaders are excluded from important areas of participation in UP which include infrastructure, budget decisions, different Standing Committees and Project Committees on UP, social and child development, immunization and nutrition projects, education, health, agriculture, salish ${ }^{1}$, maintenance of law and order and their involvement is mostly informal and marginal and women opinions are not heard during decision-making, and male colleagues behave negatively toward them. (Gani and Sattar, 2004; Khan, 2008; Khan, 2009: 9, Begum, 2005; BARC Research Report, 2007; Khan and Mohsin, 2008; Shamim and Nasreen, 2002, p.52; UNDP, 2003). Empirical research findings have testified that women members were not considered capable political actors and reserved seats members were not treated/valued as general members in the UP (Begum, 2007, p.263-64) and the male's extreme disregard for women members' roles undermined the objectives of reservation and effectively neutralized the political empowerment of women(Panday, 2008; Begum, 2007). The Chairman is placed in a relatively powerful position, and often takes decisions in conjunction with a small circle of associates, from which female members, in particular, are likely to be excluded (Aminuzzaman, 2011, p.200). Male members think that women members have nothing to do with the development of the UP, which can be observed from the utterance of a woman member from Chadpur UP, who opined the following "the male members deemed that in the UP the women members do not have any rights and obligations to do anything as they are only reserved members in UP" (Woman Member, Chadpur UP).

During interview with a woman member in the UP, she opined the following: "Women members were not given big projects rather they were provided with small projects and all the big projects were given to the male members, these were the general trends in most of the UP" (Woman Member, Bijoypur Moddham UP).

\footnotetext{
${ }^{1}$ Salish refers to informal local arbitration council for resolution of petty disputes conducted by the UP representatives.
} 
Male domination is omnipresent in the family, society, and states where women have traditionally lower positions in all spheres. In the family, the husband or father occupies the leading role. In the society it is an entirely male paradigm, and the state, the highest organ, has the right to create all policies and programs that protect the rights of men whereas the women's role is acknowledged with only some affirmative actions. Sharing her grim reality and experience, one woman, member from the Wahedpur UP stated the following:

"The women members need to be elected in the husband's residential area, so most of the women members dare to protest any wrongdoings of the male members due to their prestige concern and for avoiding criticism and for saving their due respect in the bridegroom's family" (Woman Member, Wahedpur UP).

Obviously, no one ever thinks the above reality like the woman member of Wahedpur UP. Most of the women members in Bangladesh are married. In consonance with Bangladeshi values, norms, and cultural standards, it is considered bad when a woman is bold and courageous in establishing her rights and privileges in the family and society. On the other hand, the women that consume or subsume everything and just avoid all odds, injustice, violence, oppressions and tyranny without noticing the males, especially their husband, are deemed as an "ideal" woman in the society of Bangladesh. Again, its roots are deep in the patriarchy and paternalistic social structure. The whole social structure, the power relations and mechanisms through which society is governed are entirely male biased and ruled by patriarchal values and ethos. Therefore, women members position themselves in such a manner that they are simply innocent consumers and receivers of unjust oppression, wrongdoings, and massive tyranny towards them. They find no messiah to save them from such a draconian and devastating social enemy, which has been profoundly engrained and engulfed by patriarchy and which is deemed quite insurmountable by the women members. According to Khan (2008), monopolization of the use of power by the Chairman prevents UP members from playing their effective and rightful role in UP development. This dictatorial tendency of the Chairman also creates problems in decision-making, project formulation, and financial management. Evidence has shown that what people think about women and women's place matters in terms of women's ability to attain political power (Norris and Inglehart, 2001; Paxton and Kunovich, 2003). In Bangladesh, the average person has the same attitude towards women: from the birth to death, a male is born and brought up in those patriarchal values, which no one can easily change, and this male domination is perpetuated dynasty after dynasty, generation after generation without undergoing any change in it.

Women in local government in Bangladesh have bearing on the rural life where traditional values prevail and tend to inhibit social mobility. The age-long orthodoxy in traditions and rituals dominates the outlook and aspirations of the people in the villages (Solaiman, 1998). Values function as social structure (Jahangir, 1982) and provide a background to social integration by cherishing values as an instrument of social cohesion, preventing social disorder from growing (Mashreque and Amin, 1994a). The social order of the backward rural community in Bangladesh is characterized by kinship, factionalism, and elitism (Mashreque and Amin, 1992a, 1992b, 1993a, 1993b, 1994b). With such patrimonial social characteristics, the culture of women's 
participation cannot be thought of. In fact, the domination of male members is still taken for granted in the public world of politics. Moreover, these male members use their patronage networks to influence the decision-making process. The existence of " $d e$ facto politics" clearly hinders the meaningful participation of women in politics, despite the introduction of quotas (Vijaylakshmi, 2002; cited in Mukhopadhyay, 2005, p.31). Women's vulnerability is aggravated by the practice of early and arranged marriage, polygamy, veiling or purdah $^{1}$, and the seclusion of women, which restrict their mobility, public exposure and opportunity to improve their condition. Therefore, women are to face problems of their husband's polygamous marriages, divorce, dowry demand and violence (Shamim, 2001; Shamim \& Nasreen, 2002). Obviously, the culture of effective participation in formal community activities is still non-existent (Mohammed, 2010). Though NGOs have worked hard to develop some client-based community groups (some form of social capital), still they are more concerned with their own group interest, than visible community involvement (Sharmin and Aminuzzaman, 2006 quoted in Aminuzzaman, 2011, p.201). There is no denying the fact that women's participation in local government has far-reaching ramifications for social mobility, acting on caste, occupation, sect, kinship and factionalism, which are responsible for the process of segregation and exclusiveness. The patriarchal social system runs on the recognition of male superiority and female subordination, and women are attached to low status and unequal sex relationship. The rural community in Bangladesh, therefore, is on the verge of threat of disequilibria (Amin \& Akhter, 2005, p.2).

\section{Extreme corruption plaguing women's role in the UP}

The second obstacle women leaders identified in the UP is corruption. The full verbatim of the prevalence of corruption in the UP are portrayed below with the textual narratives obtained from the women leaders in Bangladesh. Corruption is highly prevalent in most of the third world countries and Bangladesh is no exception to this case. Due to massive corruption these women leaders have miserably failed to adjust themselves in the UP. There are evidences that corruptions are galore in the spheres of the UP in Bangladesh. Transparency International, Bangladesh- (TIB) reported that since 1996, Bangladesh was the most corrupt countries in the world for the five consequent times. In TIB reports it was learnt that among many other state organizations, local government namely the UP was found severely involved in doing corrupt practices in Bangladesh, which corroborates the findings with the present study. In the following section, the way corruption takes place in the UP has been explained elaborately. In reply to a question, whether women members need to pay money, when they bring or get a project from the Chairman, one woman, member stated that:

"You know that in Bangladesh everywhere there is an established system that we have to bring project fulfilling all the respective shares of Ministers, MPs, DC, UNO, Upazila Engineers and Uparila Chairman, which has become convention and Union Parishad has no exception to this". (Woman Member, Khadimpara UP).

${ }_{1}$ Purdah is a Bengali word that stands for veil. Muslim women use it for performing their religious values and sanctity. 
Through the above quotation, the prevalence of corruption in the sphere of the UP has been reflected well. The underlying meaning reveals that the whole Bangladesh is unfortunately involved in such a social evil that destroys country's development to a considerable level. The above women included the entire state machinery in the realm of corruption. The legislators, the administration and the public representatives all are epitomized as the influential parties involved in corruption in Bangladesh. It is very interesting to note here that being the chief executive of the UP, Chairman also demands bribe from the members, which can be seen from the statement made by the women member of Khadimpara UP, who mentioned that "when we finished our projects, sometimes we share profits through mutual understandings with the Chairman". (Woman Member, Khadimpara UP).

In order to have an in-depth understanding about the magnitude of corruption at the community level, the manager of a cooperative society was also interviewed in wake of the discussion and opined that "no one could do work for the whole budget in UP. In most cases, 20-30\% money is leaked out". (Manager, Hatigara Comprehensive Village Development Cooperative Society, Comilla). Furthermore, when I asked who were involved in such corruption, he answered that:

"I did not know who were involved with it, but the UP functionaries must have this answer to them. If the members could do work with the full amount, the quality of the work. would be much better because having less amount these members (meaning both male and female members) used very low-quality materials when they conducted a project". (Manager, Hatigara Comprehensive Village Development Cooperative Society).

Corruption is one of the most draconian enemies towards the development of Bangladesh society. Due to massive corruption, lion's shares of the public resources invested for development of Bangladesh are drained out otherwise. The worst victim of corruption is the poor people of Bangladesh. This was quite evident from the above utterance that due to corrupt practices, women members cannot deliver the best work for the local people and they are to suffer a lot because women tend to be honest in their activities but being compelled with the ground realities these women leaders have learnt to compromise with the practical situation. Corruption is endemic in Bangladesh. According to TIB (2008), it was found the local government was the second most corrupt sector in Bangladesh. Corruption takes place at the local government level due the existence of patron-client relationship in the rural milieu ${ }^{1}$. The UP Chairperson and some dominant members tend to maintain strong patron-client relations with a section of rural community. Unfortunately, such clients are not necessarily the weaker or poorer section of the rural community. UP therefore tend to take some of its development management and distributive decision on the basis of such patron-client dependency syndrome (Aminuzzaman, 2011, p.204). Corruption is prevalent in distribution of social safety net benefits also. Most of the safety net programs and some

\footnotetext{
${ }^{1}$ Findings of the study reveal that a powerful network termed as dal chokra (mediators) play important role at the local governance in Bangladesh. They play intermediary role between the villagers and the ruling party leaders and the civil servants. The study confirmed three categories of mediators. The first category includes the leaders of the ruling party and dominant opposition, student leaders and the UP chairman. The second category comprises local contractors, trade union (see Asaduzzaman, 2008).
} 
development activities are designed and managed by the political workers/leaders of the ruling party under the administrative and political support of the members of parliament. UP has been kept in sideline in managing the projects (Aminuzzaman, 2011, p.206). The same phenomena are prevalent in distribution of VGD $^{1}$ cards (Asian Human Rights Commission-Hunger Alert Program Bangladesh, 2011).

\section{Empirical evidence of corruption}

Here 2 cases of corruption in Chiora UP, Comilla were illustrated briefly with a view to unfolding the forms and nature of corruption practiced in the UP. During data collection, a woman member shared a case of corruption of the Chairman of Chiora UP which she experienced very recently. That woman member experienced this case of corruption when she came to know that she had given a project of one lack taka (1191 US $\$)^{2}$ which was obtained from $1 \%$ land transfer tax from Upazila Parishad. After getting the project Chairman advised her to sign a check and thereafter the check was cashed. As soon as the check was cashed, Chairman took away the whole taka from her giving 7000 taka (83 US\$) in her hand. Another woman member shared a case of corruption of the Chairman of Chiora UP with the author. She told that once the Chairman tried to pass few projects by the UNO office using fake signatures of woman members and having doubt about its authenticity UNO immediately probed it and he was caught red handed because it was completely concocted and fake. At that time UNO warned the Chairman that he would be suspended from his Chairmanship but anyhow now he has managed everything by obtaining a stay order from the high court.

\section{Faulty legal provision imposed on women leaders in the UP}

The women members identified the reservation system as one of the formidable challenges towards ensuring their participation in UP. However, in developing women leadership some sorts of affirmative actions are needed from the government. Likewise, Bangladesh adopted the same strategy for bringing women into the public life. Evidence shows that many countries such as Afghanistan, Bangladesh, Eritrea, Jordan, Morocco, Rwanda, Somalia, Sudan, Taiwan, Tanzania, and Uganda adopted reservation quota for women (Dahlerup and Nordlund, 2004). It is observed that where reservation

\footnotetext{
1 Vulnerable Group Development (VGD) is a food based Social Safety Net Programs in Bangladesh, sponsored by World Food Program. The target group of the program is landless women who are widowed, divorced, abandoned, having under-nourished children, lactating mothers and women with handicapped husband etc. The aim of the program is to enhance food and nutrition security of women and children through improved food consumption, education, skills development, livelihood diversification and risk mitigation. To achieve objective of VGD program, currently about 3.75 million beneficiaries from ultra-poor households are provided with the provision of monthly food ration of $30 \mathrm{~kg}$ of wheat or $25 \mathrm{~kg}$ of fortified wheat flour (atta, in Bangla) for a period of 24 months, and a package of development services for human capital development.

2 One UD $\$=83.98$ taka as of 14 March 2018. The figure is calculated more or less full digit deducting the fraction amount.
} 
system has been implemented, the popular political culture has gradually become more accepting of women taking part in politics. In fact, enhanced political representation of women depends more on the political will of the government than on a nation's world economic standing or any other economic factor (Tripp, n.d., p.7). Considering the importance of women's political participation, the government of Bangladesh has made provision of $33 \%$ reservation quota for women member in the UP in 1997. In fact a strong network of women's organizations and NGOs, coupled with global women's movement and active role played by the donor agencies have helped develop the discourse of gender equality, mobilizing women at the local level, and funding their support and training (Goetz, 1996, 1997; Kabeer, 1994). Scholars opine that rather than national level, women's political participation at the local level is more important for the development of rural women. Evidence shows that women in Asia have achieved better representation at local level than that of national level ${ }^{1}$.

Goetz (2004) and Beall (2004) (quoted in Mukhopadhyay, 2005: 14) have noted that women's reservation in local government in many countries has been taken as an extra measure, rather than considering women as credible and legitimate political actors. In Bangladesh, Union Parishad Act of 1997 have helped ensure women's equal access in political power structures (Khan \& Ara, 2006) but being directly elected in the UP, women members found helpless because during preliminary stage, women members were not involved in any activities of the UP. Thereafter, in a bid to strengthen women's role and participation in the UP the concerned Ministry made a legal provision in 2002 that empowered women members to enjoy few specific rights in the UP (Rahman and Sultana, 2005).

Still there are lack of clarity and vagueness in the legal provision regarding the roles and responsibilities of the women member in UP. In my analysis, the cardinal problem towards enjoying women's rights in UP is not the reservation quota rather it is due to the attitude of the male member, women are being deprived of their rights in UP. Labeling women members as the reserved seat member, male members propagate that as women are elected in the reserved seats, so they have nothing to do with the development process in the UP. A woman member from Chadpur UP commented that "the male members deemed that in the UP the women members do not have any rights and obligations to do anything as they are only reserved members in UP" (Woman Memebr, Chadpur UP). Another woman member from Alkora UP stated that:

"In fact, the reservation system is problematic, if government changed this system, it would be better. That's why I wanted to contest election in the general ward. Without any bargaining we could not bring any project in UP” (Woman Member, Alkora UP).

The underlying assumption of the above utterance is that women are to struggle immensely for establishing their due rights in the Parishad but being occupied absolute power and authority by the male Chairman, women are time and again neglected and

\footnotetext{
${ }^{1}$ For details see Drage (2001) who found that in 2001, the Philippines had 16.5\% women; Thailand 18.1\%; China 22:1\%; Nepal 24.1\%; Vietnam 26.6\%; India 33\%; and Bangladesh 33.3\% women in their respective local governments and on the other hand Sri Lanka had 2\% and Japan had only $6.2 \%$ women in local government.
} 
denied their enshrined rights and share in the UP. The provision of direct election contributed to increase women's motivation to contest in the UP election in huge numbers in 1997 but being failed to ensure their rights in the UP, the number of candidates contesting in the next election in 2003 drastically reduced ${ }^{1}$. The reserved seats female members virtually have no power in the decision-making process compared to the general seat members as they failed to obtain enough institutional status and support and are denied access to mainstream activities. Khan (2009, p.9) found that women are excluded from all important activities in the UP due to being elected as the "reserve seat members", which created un-clarity and vagueness in the existing law and provided scope for taking all decision by men. Out of 4498 UPs, it was found that there are only 24 Women Chairpersons and the rest 4474 UPs are run by the male Chairmen and the UP structure is structured in such a way that it has become a one man parishad as all powers and authority is vested on the Chairman. This Chairman is the bearer of important symbol of the male domination and patriarchy supported by other 9 male members in UP. Therefore, female members are deprived of their due rights and share in UP. However, after getting the legal provision of assigning one-thirds of the total projects, amidst fighting to establish their legal rights, a few women have become successful to get few projects. But anyhow while they implement projects, the male members of that ward sometimes create obstacle for her. Therefore, all women members have skeptical view about the reservation system in UP.

\section{Conclusions}

Based on the available evidences, case studies and phenomenological analysis from textual descriptions of the women leaders in the UP it was paradoxically evident that the problems towards ensuring women leaders' efficacious role and participation are male domination or patriarchy, corruption and faulty legal provision practiced for the WLs in the UP. Unfortunately, all these major problems are in fact the problems of governance of Bangladesh society as well. To redress male domination and corruption, the UP structure should be rationalized, and women's reservation quota should be upgraded to $50 \%$ from $33.33 \%$. In Bangladesh, women's role in the society is conditioned by various socio-cultural impositions such as patriarchy, purdah, religious superstitions, etc., so education facilities can be expanded, which can help in the transformation of traditional restrictive attitudes and modification of cultural norms and practices embedded in the social milieu. Orthodox cultural beliefs create problems for women in terms of taking part in political space, whereas liberal values facilitate

\footnotetext{
${ }^{1}$ Due to the provision of direct election, it was observed that in the UP election of $1997,85 \%$ women voted (Islam, 2000; Begum, 2002, p.101). But being deprived of their rights in UP, in the next election of 2003, in total 39,419 women contested for 12,669 quota seats, which represents the fact that number of women contested in UP election declined from 44,969 in 1997 to 39,419 in 2003, which is about a quarter (12.3\%) and around half of women members (47\%), who were elected in $1997 \mathrm{did}$ not compete in the 2003 elections (Karmaker, 2006; Steps Towards Development, 2003: 7). In the 1997 UP election, 44,969 women contested in quota seats reserved for them, and of them, 13,437 women were elected. In the same year among 13,437 women members, 592 were elected unopposed and uncontested. In the 2003 UP election, 39,419 rural women contested in 12,669 quota seats in the UP (Islam, 2000: 112-13; Begum, 2002; Karmaker, 2006; Pandey, 2008; Islam and Islam, 2012).
} 
Paradoxes of participation of the women leaders in the Union Parishad in Bangladesh | 71

women's political participation and education is perhaps the only mechanism through which value change occurs and society develops. Therefore, progressive and liberal thinking should be promoted through expansion of education facilities and democratic governance to strengthen women leadership in the UP and Bangladesh as well.

\section{References}

ADB (2001). Technical Assistance for Gender and Governance Issues in Local Government. Dhaka: ADB.

Alam, Bilkis Ara \& Begum, R. A. (1974). Violence and Union Parishad Leadership: A Few Statistics, Local Government Quarterly, 8 (1-4).

Aminuzzaman, S. M. (2011). Local Governance Innovations: An Assessment of the Challenges for Mainstreaming Local Governance Support Program. In I. Jamil, S. M. Aminuzzaman, S. Askvik, \& S. M. H. Tawfique (Ed.). Understanding Governance and Public Policy in Bangladesh. North South University, Bangladesh: Master in Public Policy and Governance Program.

Asaduzzaman, M. (2008). Governance in Practice: Decentralization and Peoples Participation in the Local Development of Bangladesh (Unpublished Doctoral Dissertation). The University of Tempera, Helsinki, Finland.

Beall, J. (2004). Decentralization and Engendering Democracy: Lessons from Local Government Reform in South Africa. Working Paper No. 54. London: Crisis States Program, Development Research Centre.

Begum, A. (2005). Judicial Activism Vs. Judicial Restraint: Bangladesh's Experience with Women's Rights with Reference to the Indian Supreme Court. Journal of Judicial Administration, XIV (4), 227.

Begum, A. (2007). Local Governance in Bangladesh: Towards A "Critical Mass" to Combat Discrimination against Women with Special Reference to India. Journal of Social Science, Vol. XIV (3), 263-64.

BRAC Research Report. (2007). Research Report 2007. Retrieved from http://Www. Bracresearch. (accessed on 14 March 2018).

Chafetz, J. S. (1990). Gender Equity: An Integrated Theory of Stability and Change. Newbury Park: Sage.

Chowdhury, N. J. (2005). Empowerment in Bangladesh: Some Concepts and Concerns. Empowerment, 12:17-34.

Chowhdury, N., Begum, H. A., Islam, M., \& Mahtab, N., (1994). (Eds.). Women and Politics. Dhaka: Women for Women.

Dahlerup, D., \& Nordlund, A. T. (2004). Gender Quotas: A Key to Equality? A Case Study of Iraq and Afghanistan. European Political Science, 3(91), 8.

Drage, J. (2001). Women in Local Government in Asia and the Pacific: A Comparative Analysis of Thirteen Countries, Report for the ESCAP, 34. Retrieved from http: www.citieslocalgovernments.org/101a/upload/docs/womeninurbanlocalgovernment. (Comparative Analysis 13 countries.pdf).

Forbes, G. (2002). Women of Character, Grit and Courage: The Reservation Debate in Historical Perspective. In L. Sarker, K. Sharma \&D L. Kasturi (Eds.). Between Tradition, Counter Tradition and Heresy. Delhi: Rainbow Publishers.

Gani, M. S., \& Sattar, M. G. (2004). Gender and Good Governance Issues in Local Government of Bangladesh: A Baseline Report. Dhaka: Research and Evaluation Division, BRAC.

Goetz, A. M. (1997). (Ed.). Getting Institutions Right for Women in Development. London: Zed Books. 
Goetz, A. M. (2004). Decentralization and Gender Equality. In UNDP Report for Beijing +10, Striving for Gender Equality in an Unequal World. Geneva: UNDP.

Harris, C. (2001). Barriers Remain for Women. The Press, 6 July, 5.

Hasmi, T. I. (2000). Women and Islam in Bangladesh: Beyond Subjection and Tyranny. New York: St. Martin's Press, Inc.

Huq, J. (1995). Empowerment of Women in Bangladesh: The Rural Scenarios. In R. Jahan, S. R. Qadir, H. A. Begum, \& J. Huq (Eds.). Empowerment of Women: Nairobi To Beijing (19851995). Dhaka: Women for Women, p. 60-65.

Inter-Parliamentary Union (2000). Politics: Women's Rights. Geneva, Switzerland: InterParliamentary Union (IPU).

Islam, M. S. (2000). Political Empowerment of Women in Bangladesh in World Perspective: An Analysis. Rajshabi University Studies, Part C, Vol. 8. Rajshahi: University of Rajshahi.

Islam, T. \& Islam E., (2012). Barriers and Scope of Political Participation of Women in Local Government of Bangladesh: UP Perspectives, Journal of International Social Issues, 1 (1), 71-85

Jahangir, B. K. (1982). Rural Society, Power Structure and Class Practice. Dhaka: CSS, Dhaka University.

Kabeer, N. (1994). Reversed Realities: Gender Hierarchies in Development Thought. London: Verso.

Karmaker, R. (2006). New Steps Promoting Gender Equality Human Rights and Good Governance. Issue 5. Dhaka: Steps Towards Development from NGO Anti-Poverty Efforts'. Development and Practice. 5 (2), 108-16.

Khan, M. M. (2008). Functioning of Local Government (Union Parishad), Research Report, Democracy Watch, USAID. Dhaka: Democratic Local Governance Program DLGP, TRI International.

Khan, M. M. (2011). Local Government in Bangladesh: Some Contemporary Issues and Practices, Dhaka: A. H. Publishing House.

Khan, M. M. R. \& Ara, F. (2006). Women, Participation and Empowerment in Local Government: Bangladesh Union Parishad Perspectives, Asian Affairs, 29 (1), 73-100.

Khan, Z. R. (2009). LGSP- LIC Study of Women's Participation in Local Development in the LIC Districts in Bangladesh. Dhaka: Local Government Division, GOB.

Mahtab, N. (2007). Women in Bangladesh from Inequality to Empowerment. Dhaka: AH Development Publishing House.

Mashreque, M. S. \& Amin, M. Ruhul (1992a): Politics of Factionalism in Rural Bangladesh. LASSI Quarterly, X (4).

Mashreque, M. S. \& Amin, M. Ruhul (1992b). Patron-Client Relations and Fictive Kinship in Bangladesh. The Eastern Anthropologist, October-November.

Mohammed, S. N. (2010). People's Participation in Development Projects at Grassroots Level: A Case Study of Alampur and Jagannathpur Union Parishad, Unpublished Master Thesis, Master of Public Policy And Governance (MPPG), North South University.

Norris, P., \& Inglehart, R. (2001). Cultural Obstacles to Equal Representation. Journal of Democracy, 12(126), 140.

Panday, K. P. (2008). Representation without Participation: Quotas for Women in Bangladesh. International Political Science Review, 29 (4), 489-512. Retrieved March 15th 2014, from http://ips.sagepub.com/content/29/4/489.refs.html.

Paxton, P., \& Hughes, M. M. (2007). Women, Politics and Power: A Global Perspective. Los Angeles, London, New Delhi, Singapore: Pine Forge Press.

Paxton, P., \& Kunovich, S. (2003). Women's Political Representation: The Importance of Ideology. Social Forces, 81(5), 87-114. 
Paradoxes of participation of the women leaders in the Union Parishad in Bangladesh | 73

Rasiduzzaman, M. (1968). Politics and Administration in the Local Councils in East Pakistan. London: Oxford University Press.

Rule, W. (1994). Women's Under-Representation and Electoral Systems. Political Science \& Politics, 27(4), 689-92.

Shamim, I., \& Nasreen, M. (2002). Gender and Local Governance: A New Discourse in Development. Journal of Social Studies, 94/95, October-March, 50-87.

Sharmin, S., \& Aminuzzaman, S. (2006). Governance Mapping: Pro-Poor Governance in Rural Bangladesh. p.165-177. In Salahuddin A. (Ed.) Governance and Development: Bangladesh and Regional Experiences. Dhaka: Shravan Publishers.

Siddiqui, K. (1995). Local Government in Bangladesh. Dhaka: University Press Limited.

Sikder, T., Engali, J., Byrne, S., \& Tabet, T. (2011). Socially Inclusive Local Governance-Case Study: Sharique-Bangladesh. Dhaka: Inter-Cooperation, Institute of Development Studies, The Democratization and Local Government Network.

Smock, A. C. (1977). Bangladesh: A Struggle with Tradition and Poverty. Chapter Three. In J. Z. Giele and A. C. Smock. (Ed.). Women: Roles and Status in Eight Centuries. New York, London, Sydney, Toronto: John Wiley \& Sons.

Solaiman, M. (1998). Participation of Women in Politics in Bangladesh, Paper Presented For Presentation at the CIRDAP: British Council Regional Workshop on "Toward Gender Equity: Poverty Rights And Participation” Held in CIRDAP During 15-19 February, 1998.

Stalker, P. (1995). A Fork in the Path: Human Development Choices for Bangladesh. Dhaka: United Nations.

TIB (2008). National Household Survey 2007 on Corruption in Bangladesh. Dhaka: TIB.

Retrieved from:

http://www.tibangladesh.org/research/hhsurvey07full180608\%5b2\%5d.pdf, accessed on 21 February 2017

Tripp, Aili Mari (n.d.). New Trends in Women's Political Participation in Africa. $<$ http://www.democracy.standford.edu/seminar/ailitripp.pdf >. accessed 15 January 2018.

UNDP (1993). Human Development Report 1993. New York: UNDP.

United Nations (2007). Indicators of Literacy. United Nations Statistics Division. $<$ http://unstats.unorg/unsd/demographic/products/socind/literacy.htm> Accessed 15 January 2017.

Wollack, K. (2010). Women as Agents of Change: Advancing the Role of Women in Politics and Civil Society. A statement given at the house committee on foreign affairs. 